\title{
Longitudinal assessment of dairy farm management practices associated with the presence of psychrotolerant Bacillales spores in bulk tank milk on 10 New York State dairy farms
}

\author{
S. N. Masiello, ${ }^{*}$ D. Kent, ${ }^{*}$ N. H. Martin, ${ }^{*}$ Y. H. Schukken, $\dagger^{1}$ M. Wiedmann, ${ }^{*}$ and K. J. Boor ${ }^{* 2}$ \\ *Milk Quality Improvement Program, Department of Food Science, and \\ †Quality Milk Production Services, College of Veterinary Medicine, Cornell University, Ithaca, NY 14853
}

\begin{abstract}
The ability of certain spore-forming bacteria in the order Bacillales (e.g., Bacillus spp., Paenibacillus spp.) to survive pasteurization in spore form and grow at refrigeration temperatures results in product spoilage and limits the shelf life of high temperature, short time (HTST)-pasteurized fluid milk. To facilitate development of strategies to minimize contamination of raw milk with psychrotolerant Bacillales spores, we conducted a longitudinal study of 10 New York State dairy farms, which included yearlong monthly assessments of the frequency and levels of bulk tank raw milk psychrotolerant spore contamination, along with administration of questionnaires to identify farm management practices associated with psychrotolerant spore presence over time. Milk samples were first spore pasteurized $\left(80^{\circ} \mathrm{C}\right.$ for $\left.12 \mathrm{~min}\right)$ and then analyzed for sporeformer counts on the initial day of spore pasteurization (SP), and after refrigerated storage $\left(6^{\circ} \mathrm{C}\right)$ for 7,14 , and $21 \mathrm{~d}$ after SP. Overall, $41 \%$ of samples showed sporeformer counts of $>20,000 \mathrm{cfu} / \mathrm{mL}$ at $\mathrm{d} 21$, with Bacillus and Paenibacillus spp. being predominant causes of high sporeformer counts. Statistical analyses identified 3 management factors (more frequent cleaning of the bulk tank area, the use of a skid steer to scrape the housing area, and segregating problem cows during milking) that were all associated with lower probabilities of d-21 Bacillales spore detection in SPtreated bulk tank raw milk. Our data emphasize that appropriate on-farm measures to improve overall cleanliness and cow hygiene will reduce the probability of psychrotolerant Bacillales spore contamination of bulk tank raw milk, allowing for consistent production of raw milk with reduced psychrotolerant spore counts,
\end{abstract}

Received May 9, 2017.

Accepted July 16, 2017.

${ }^{1}$ Current address: Department of Animal Science, Wageningen University, Wageningen, the Netherlands.

${ }^{2}$ Corresponding author: kjb4@cornell.edu which will facilitate production of HTST-pasteurized milk with extended refrigerated shelf life.

Key words: Bacillus spp., Paenibacillus spp., spoilage, management practice

\section{INTRODUCTION}

Bacterial spoilage is the predominant limiting factor in the shelf life of pasteurized fluid milk (Boor, 2001; Durak et al., 2006). In the absence of postpasteurization contamination of the product, spore-forming bacteria are the predominant residual organisms in pasteurized fluid milk. Gram-positive Bacillus spp. and Paenibacillus spp. form heat-resistant spores that are able to withstand the $\operatorname{HTST}\left[72^{\circ} \mathrm{C}\left(161^{\circ} \mathrm{F}\right), 15 \mathrm{~s}\right]$ pasteurization commonly used for fluid milk processing (Collins, 1981; Fromm and Boor, 2004; Ranieri et al., 2009), with certain strains able to grow at refrigerated storage temperatures, resulting in milk spoilage (Washam et al., 1977; Huck et al., 2008). Previous work identified Bacillus spp. as predominant sporeformers early in the refrigerated shelf life of fluid milk, whereas the prevalence of Paenibacillus increased over shelf life (Fromm and Boor, 2004; Ranieri et al., 2009). Characterization of bacterial isolates showed that only a few specific Bacillus species (e.g., Bacillus weihenstephanensis) but many Paenibacillus species are able to grow during refrigerated storage of milk. These spore-forming spoilage bacteria, via metabolic activities, can lead to loss of product quality (e.g., curdling, off-odors or off-flavors; Ageitos et al., 2007; Dutt et al., 2009). Controlling these psychrotolerant Bacillales spores in raw milk is critical to the extension of fluid milk shelf life.

Elimination of psychrotolerant spore-forming bacteria is challenging as they are found throughout the general environment (e.g., soil, decaying matter, plant surfaces, mammalian digestive tracts; Gilliam et al., 1984; Gilliam, 1985; Sarkar, 1991; Fredrickson and Onstott, 1996; Nicholson, 2002) and, more specifically, the dairy farm environment. For example, Bacillus spp. were frequently isolated on Scottish dairy farms, from 
both the dairy farm environment and raw bulk tank milk (Crielly et al., 1994). Paenibacillus spp. have also been isolated from silage, dairy cow feed concentrate, and raw milk (Vaerewijck et al., 2001; te Giffel et al., 2002; Scheldeman et al., 2004). In a recent study in the United States, spore-forming psychrotolerant bacteria were isolated from samples taken along the dairy processing continuum from milk trucks to packaged final products; identification of the same bacterial subtypes in both raw and pasteurized milk samples suggests that pasteurized fluid milk spoilage can result from spores that originate from raw milk on the farm (Huck et al., 2007b).

A previous cross-sectional study on the relationship between on-farm management practices and psychrotolerant Bacillales spore levels in bulk tank milk from 99 dairy farms in New York State (NYS) found that practices related to milking time hygiene may influence the levels of spores present in bulk tank raw milk (Masiello et al., 2014). Specifically, improved udder cleanliness was linked to reduced psychrotolerant Bacillales spore counts (Masiello et al., 2014). Due to the cross-sectional nature of that study, it did not evaluate how spore levels or management practices may change over time on a dairy farm. Exploring the factor of time is important, because previous work has identified associations between the isolation of psychrotolerant Bacillus spp. from fluid milk and specific seasons (Phillips and Griffiths, 1986; Griffiths and Phillips, 1990; Sutherland and Murdoch, 1994). For example, studies on both bulk tank and pasteurized milk in Scotland found that psychrotolerant spore-forming bacteria were more commonly isolated in the summer and autumn months (Phillips and Griffiths, 1986; Griffiths and Phillips, 1990). Another Scottish study exploring seasonal occurrence found that psychrotolerant Bacillus spp. were most prevalent during the summer and autumn months whereas mesophilic (growth at $30^{\circ} \mathrm{C}$ for $72 \mathrm{~h}$ ) Bacillus spp. often dominated in the winter months (Sutherland and Murdoch, 1994).

We hypothesized that specific farm-associated factors, including on-farm management practices and seasonal factors, may be associated with psychrotolerant spore contamination of bulk tank raw milk. With the goal of future development of specific recommendations for management of spore numbers in bulk tank milk, the objectives of this study were to (1) assess and characterize psychrotolerant spore contamination patterns in bulk tank milk across and within dairy farms over time; and (2) evaluate the associations of on-farm management practices and seasonal factors with psychrotolerant spore contamination in bulk tank milk over the course of $1 \mathrm{yr}$.

\section{MATERIALS AND METHODS}

\section{Farm Selection}

A longitudinal study with monthly sampling repetitions was conducted on 10 NYS dairy farms from February 2011 to February 2012 (excluding December 2011). Herds were selected from the Quality Milk Production Services (QMPS; College of Veterinary Medicine, Cornell University, Ithaca, NY) program clientele at 4 QMPS locations, representing 4 regions in NYS, including regions surrounding Ithaca (3 farms), Canton (2 farms), Cobleskill (3 farms), and Geneseo (2 farms). Farms were selected based on willingness to participate and previous classification of psychrotolerant Bacillales spore levels, as described by Masiello et al. (2014). Specifically, 5 farms previously identified as having a "high" psychrotolerant Bacillales spore level [ $\geq 3 \log \mathrm{cfu} / \mathrm{mL}$ after $21 \mathrm{~d}$ of $6^{\circ} \mathrm{C}$ storage after spore pasteurization $\left.\left(80^{\circ} \mathrm{C}, 12 \mathrm{~min}\right)\right]$ and 5 farms previously identified as having a "low" psychrotolerant Bacillales spore level $\left(<3 \log \mathrm{cfu} / \mathrm{mL}\right.$ over all $21 \mathrm{~d}$ of $6^{\circ} \mathrm{C}$ storage after spore pasteurization) were included in the study. All participants were fully informed of the design of the study, the nature of the data being collected, and their future use, and all were aware that their participation in the study was voluntary. Each participant signed an informed consent document acknowledging the above items.

\section{Farm Characteristics}

Herd sizes ranged from 32 to 1,368 cows, with a mean herd size of $535 \pm 480$ cows. Cows were housed in freestalls $(65 \%)$, tiestalls $(25 \%)$, or on pasture $(10 \%)$. Cow breeds included Holstein (60\%) and multiple or mixed breeds (40\%). The number of lactating cows per farm ranged from 26 to 909 (mean of $371 \pm 326$ lactating cows), with farms milking between 2 and 4 times daily $(30 \%$ at $2 \times, 60 \%$ at $3 \times$, and $10 \%$ at $4 \times)$. Average milk production across farms was $10,821 \pm 2,714 \mathrm{~kg}$ $(23,857 \pm 5,984 \mathrm{lb})$ per cow per year and ranged from 4,468 to $14,250 \mathrm{~kg}(9,850$ to $31,415 \mathrm{lb})$.

\section{Survey Design}

The survey used in this study was modified from an existing QMPS survey that included questions on herd health, housing cleanliness, equipment maintenance, milking time procedures, and medication usage (Table 1 ). The modified survey included 4 pages previously used by QMPS and 1 page that focused on specific potential risk factors deemed relevant for spore contamination (Table 1); the supplemental 1-page survey 
Table 1. Summary of farm management practice data collected from surveys administered each month for a year $(\mathrm{n}=12 \mathrm{sampling}$ visits per farm) for 10 farms in New York State

\begin{tabular}{|c|c|}
\hline Factor $^{1}$ & Description $^{2}$ \\
\hline Seasonal factors & Month of sampling \\
\hline Herd health & $\begin{array}{l}\text { Percent of cows with unhealthy teats, percent of cows with injured teats, selenium added to feed, selenium injection } \\
\text { given, number of clinical cases of mastitis per month, number of lactating cows treated for mastitis each month, } \\
\text { lactating cow mastitis treatment used, number of cows that died in the prior year due to mastitis, Escherichia coli } \\
\text { vaccination given to milking cows, treatment given to dry cows, timing of dry off for cows, problem cows sold, } \\
\text { California Mastitis Test used }\end{array}$ \\
\hline Cow hygiene ${ }^{3}$ & $\begin{array}{l}\text { Cow hygiene score in milking area, percent dirty udders in the milking parlor, cow hygiene score in housing area, } \\
\text { percent dirty udders in the housing area, tail docking, udder clipping }\end{array}$ \\
\hline Milking routine ${ }^{3}$ & $\begin{array}{l}\text { Gloves worn during milking, average milking time, use of udder prep, type of udder prep, products used in udder } \\
\text { prep, are udders washed, product used to wash udders, how are udders dried, use of forestripping, problem cows } \\
\text { segregated during milking, problem cows milked last, problem cows milked with separate unit, number of milking claw } \\
\text { falloffs, number of milking claw kickoffs, number of milking claw falloffs into manure, number of milkers each day, } \\
\text { number of milkers each week, number of milkers each month }\end{array}$ \\
\hline Housing ${ }^{3}$ & $\begin{array}{l}\text { Cleanliness of lactation cow housing, type of lactation cow housing, type of bedding used in lactation cow housing } \\
\text { area, cleanliness of dry-cow housing, type of dry-cow housing, type of bedding used in dry-cow housing area, } \\
\text { cleanliness of maternity pen, type of maternity pen housing, type of bedding used in maternity pen, type of cleaning } \\
\text { method for housing areas, frequency of cleaning of housing areas }\end{array}$ \\
\hline Sanitation $^{3}$ & $\begin{array}{l}\text { Milking unit sanitation, type of sanitizers used, milking hose alignment, milking units sanitized between milking } \\
\text { groups, frequency of milking unit sanitation, parlor deck washed, frequency of parlor deck wash }\end{array}$ \\
\hline Equipment & $\begin{array}{l}\text { Make of milking claw, manufacturer of milking claw, vacuum shut off of milking units, rubber equipment changed on a } \\
\text { schedule, frequency of equipment service }\end{array}$ \\
\hline
\end{tabular}

had previously been used in a cross-sectional study (Masiello et al., 2014). The survey was designed to be administered verbally to the participant.

\section{Survey Administration and Bulk Tank Sampling}

Each location had a designated and trained QMPS technician who administered the survey and collected samples. Technicians administering the survey were trained to obtain objective answers without being leading, to focus on quantitative/numeric answers, and to follow training guides for any necessary subjective scores or observations (e.g., percent of dirty udders in the milking parlor). Farm visits occurred every month from February 2011 to February 2012, except for December 2011; both bulk tank sample collection and survey administration were performed at each farm visit.

Bulk tank raw milk at each farm was sampled using 2 sterile dip vials and one national DHIA (Verona, WI) vial; vials were immediately stored on ice packs in a cooler and held at $\leq 6^{\circ} \mathrm{C}$. Bulk tank raw milk samples ( $250 \mathrm{~mL}$ in each of 2 vials) were shipped overnight to the Milk Quality Improvement Program laboratory (Department of Food Science, Cornell University, Ithaca, NY) in Styrofoam coolers packed with ice packs. Sample temperature was recorded immediately upon arrival at the laboratory. Any samples with temperatures $>6^{\circ} \mathrm{C}$ upon arrival were rejected and the farm was resampled. The DHIA vials were shipped directly from QMPS locations to Dairy One (Ithaca, NY) for bulk tank somatic cell count (BtSCC) analysis using a Fossomatic FC ESCC automated SCC reader (Foss Inc., Hillerød, Denmark).

\section{NYS Monthly Weather Data Collection}

Average monthly weather data for each of the 4 QMPS regions were obtained from the North East Regional Climate Center (Cornell University, Ithaca, NY). The data were collected via weather stations located in Ithaca, Canton, Cobleskill, and Avon $(<16 \mathrm{~km}$ from Geneseo, NY). The monthly data collected included maximum, minimum, and average temperature, total precipitation, total snowfall, and average snow depth. 
Monthly weather data were obtained for the period of February 2011 to February 2012, excluding December 2011.

\section{Microbiological Evaluation of Milk Samples}

For each farm sampling, the 2 sample vials $(250 \mathrm{~mL}$ each) were commingled into one sterile $500-\mathrm{mL}$ glass bottle. Raw milk samples were completely inverted 25 times before removal of an aliquot for microbiological analyses, which included (1) total bacteria count (TBC) on standard plate count agar (SPCA) (Difco, BD Diagnostics, Franklin Lakes, NJ) as described by Laird et al. (2004); (2) psychrotrophic bacteria Count (PBC; Laird et al., 2004) and (3) preliminary incubation (PI) count (Martin et al., 2011).

The remaining raw milk was distributed equally among 3 sterile $250-\mathrm{mL}$ glass bottles for spore pasteurization (SP), which was performed by heat treating each of the 3 bottles ( $150 \mathrm{~mL}$ each) at $80^{\circ} \mathrm{C}$ for $12 \mathrm{~min}$, followed by immediate cooling on ice. After cooling to $6^{\circ} \mathrm{C}$, the samples in each bottle were commingled into a sterile $500-\mathrm{mL}$ glass bottle. The bottle was fully inverted 25 times and two $100-\mu \mathrm{L}$ aliquots were plated on SPCA to determine the "day initial" (DI) mesophilic spore count (after incubation at $32^{\circ} \mathrm{C}$ for $48 \mathrm{~h}$ ). The remaining $\mathrm{SP}$ milk samples were then split equally into the three 250$\mathrm{mL}$ glass bottles previously used during $\mathrm{SP}$ and held at $6^{\circ} \mathrm{C}$ for microbiological testing (TBC) at 7, 14 and $21 \mathrm{~d}$ post-SP. Additionally, a modified 5-tube most probable number (MPN) method (Davidson et al., 2004) was used to quantify psychrotolerant Bacillales spore levels below or around the detection limit of direct plating $(10 \mathrm{cfu} / \mathrm{mL})$. The MPN method was performed on SP samples as follows: $10 \mathrm{~mL}$ of $\mathrm{SP}$ milk was aliquoted into each of 5 sterile screw-capped tubes, $1 \mathrm{~mL}$ of $\mathrm{SP}$ milk was aliquoted into each of 5 sterile screw-capped tubes containing $9 \mathrm{~mL}$ of sterile skim milk broth (1:10 dilution) and finally, $0.1 \mathrm{~mL}$ of SP milk was aliquoted into each of 5 sterile screw-capped tubes containing 9.9 $\mathrm{mL}$ of sterile skim milk broth (1:100 dilution). Each of the 15 tubes was vortexed and then incubated at $6^{\circ} \mathrm{C}$ for $21 \mathrm{~d}$ before spiral plating on SPCA. Plates were evaluated for presence or absence of growth after $48 \mathrm{~h}$ of incubation at $32^{\circ} \mathrm{C}$. The MPN data were interpreted using a 5-tube MPN table (Davidson et al., 2004).

\section{Bacterial Isolate Collection}

Bacterial colonies representing visually distinct morphologies (typically 1 to 4 colonies per plate) were selected and streaked for purity on brain heart infusion (BHI) agar (Difco) from SPCA plates used for bacterial enumeration on each sampling date (DI, d
7, d 14, d 21). The BHI agar plates were subsequently incubated at $32^{\circ} \mathrm{C}$ for $24 \mathrm{~h}$. Pure cultures were grown overnight in $\mathrm{BHI}$ broth at $32^{\circ} \mathrm{C}$ before freezing in $15 \%$ glycerol at $-80^{\circ} \mathrm{C}$. A total of 746 isolates were collected using this approach. Isolate information can be found at www.foodmicrobetracker.com.

\section{Molecular Characterization and Identification of Isolates}

Sequencing data for a 632-bp fragment of rpoB, as described by Huck et al. (2007a), were used for characterization and species identification of Bacillales spore isolates obtained from SP milk samples plated on DI, d 7, 14, and 21. Briefly, cultures were streaked for colony isolation from frozen stock onto BHI agar and grown at $32^{\circ} \mathrm{C}$ for $24 \mathrm{~h}$. A sterile toothpick was used to sample an isolated colony, which was used for lysate preparation and subsequent PCR to amplify a 740-bp rpoB fragment, following previously described procedures (Ivy et al., 2012). After verifying amplification by gel electrophoresis, DNA fragments were treated with Exonuclease I (Affymetrix, Santa Clara, CA) and Shrimp Alkaline Phosphatase (New England Biolabs, Ipswich, MA), as described by Dugan et al. (2002), and bidirectional sequencing with PCR primers was performed by the Life Sciences Core Laboratory Center (Cornell University, Ithaca, NY) using Sanger sequencing. The rро $B$ sequence alignment and assignment of $r p o B$ allelic types (AT) was performed as described by Ivy et al. (2012); rpoB-based classification to genus and species was performed as described by Miller et al. (2015b). For isolates that could not be classified to genus and species by rpoB sequencing, partial $16 \mathrm{~S}$ rDNA sequencing was used to facilitate genus and species classification as previously described (Ivy et al., 2012). If definitive species identification was not possible but isolates closely resembled a named species, species were classified as "cf." (defined as "confer"; e.g., P. cf. peoriae), where cf. denotes an uncertain identification.

\section{Data Analyses}

Bacillales spore count data and raw milk test data were logarithmically transformed before analyses. Pearson's product-moment correlations were calculated between all milk tests (raw milk TBC, PBC, PI, BtSPCC, DI through d 21 Bacillales spore count, and MPN) within RStudio (version 0.98.484; RStudio, 2012) using $\mathrm{R}$ statistical software ( $\mathrm{R} \times 64$ v 3.0.2; $\mathrm{R}$ Core Team, 2014). Correlation coefficients were tested for significance using $t$-tests, and Holm-Bonferroni multiple testing correction was performed. Additionally, a Fisher's Exact Test was performed in SAS (version 9.3; 
SAS Institute Inc., Cary, NC) to explore the difference in number of Bacillus and Paenibacillus spp. isolates obtained each month.

To assess potential associations between d 21 Bacillales spore data and management practices and weather, a logistic regression was used. This analysis was performed within $\mathrm{R}$ studio (version 0.98.484) using $\mathrm{R}$ statistical software ( $\mathrm{R}$ x64 v 3.0.2; Miller et al., 2015a). Using the lme 4 (Bates et al., 2013) and dplyr (Wickham and Francois, 2016) packages, the best fitting model was determined via forward-stepwise selection based on the Akaike information criterion (AIC; Akaike, 1998). The AIC for the trivial random-effects only model was calculated and compared with the AIC of models with one explanatory variable added (i.e., a candidate model). If none of the candidate models had a lower AIC than the starting model, the selection terminated. Otherwise, the candidate model with the lowest AIC was chosen as the current model, and the process of adding one explanatory variable began again. "Farm" was included as a random factor. Interactions were not considered, and autocorrelation was not assessed.

\section{RESULTS}

\section{Bacterial Counts Across Farms}

A total of 120 bulk tank raw milk samples were collected across the 10 participating farms, using monthly sampling for a year. After SP treatment and subsequent incubation at $6^{\circ} \mathrm{C}$, each participating farm had at least one sample with a bacterial count $>1.0 \log _{10} \mathrm{cfu} / \mathrm{mL}$ after $21 \mathrm{~d}$ of refrigerated storage (Table 2). Overall mean bacterial counts (inclusive of all farms for all months; $n$ $=120$ milk samples) increased over $21 \mathrm{~d}$ post-SP; with mean bacterial counts of $2.00 \pm 1.0 \log _{10} \mathrm{cfu} / \mathrm{mL}$ (DI), $2.1 \pm 1.1 \log _{10} \mathrm{cfu} / \mathrm{mL}(\mathrm{d} 7), 3.4 \pm 1.8 \log _{10} \mathrm{cfu} / \mathrm{mL}(\mathrm{d}$ 14 ), and $4.4 \pm 2.2 \log _{10} \mathrm{cfu} / \mathrm{mL}(\mathrm{d} 21)$.

The d 21 post-SP bacterial counts varied by month and farm (Table 2). Of the 120 samples analyzed, 37 showed no signs of psychrotolerant sporeformer growth over $21 \mathrm{~d}$, whereas 49 milk samples (41\%) had d 21 post-SP bacterial counts $>20,000 \mathrm{cfu} / \mathrm{mL}(>4.3 \mathrm{log}$; Table 2). Of the samples where psychrotolerant spores were present, the monthly average d 21 counts (across all farms combined) ranged from 3.4 to $5.8 \log _{10} \mathrm{cfu} /$ $\mathrm{mL}$ during the year-long study period, whereas the farm-average d 21 counts (across all months combined) ranged from 2.1 to $6.4 \log _{10} \mathrm{cfu} / \mathrm{mL}$. For 2 study farms (H and I), all 12 milk samples for each farm had d 21 post-SP bacterial counts $<20,000 \mathrm{cfu} / \mathrm{mL}(<4.3 \mathrm{log})$. On the other hand, one farm (C) had d 21 post-SP bacterial counts $>4.5 \log _{10} \mathrm{cfu} / \mathrm{mL}$ for all 12 samples collected.
The geometric mean BtSCC among the 120 raw milk samples was 208,300 cells $/ \mathrm{mL}\left(5.3 \pm 0.3 \log _{10}\right.$ cells $\left./ \mathrm{mL}\right)$. Raw milk TBC ranged from 419 to $13,900,000 \mathrm{cfu} / \mathrm{mL}$, with a geometric mean raw milk TBC of $10,000 \mathrm{cfu} /$ $\mathrm{mL}\left(4.0 \pm 1.0 \log _{10} \mathrm{cfu} / \mathrm{mL}\right)$. The PI counts for all milk samples ranged from 756 to $22,000,000 \mathrm{cfu} / \mathrm{mL}$, with a geometric mean PI count of $52,000 \mathrm{cfu} / \mathrm{mL}(4.7 \pm$ $\left.1.2 \log _{10} \mathrm{cfu} / \mathrm{mL}\right)$. The PBC for raw milk ranged from below the detection limit $(<10 \mathrm{cfu} / \mathrm{mL})$ to $13,300,000$ $\mathrm{cfu} / \mathrm{mL}$, with a geometric mean PBC of $900 \mathrm{cfu} / \mathrm{mL}$ $\left(3.0 \pm 1.4 \log _{10} \mathrm{cfu} / \mathrm{mL}\right)$ among the 108 samples with detectable counts. The MPN for psychrotolerant Bacillales spores (determined on SP-treated milk incubated at $6^{\circ} \mathrm{C}$ ) ranged from $<0.01$ (18 samples) to $>24 \mathrm{MPN} /$ $\mathrm{mL}$ (6 samples), with a mean MPN of $0.9 \pm 2.2 \mathrm{MPN} /$ $\mathrm{mL}$ among the 99 samples with detectable MPN.

The correlation analysis showed that MPN was significantly $(P<0.05)$ correlated with DI through d 21 Bacillales spore counts, as well as raw milk BtSCC, TBC, and PI counts, with coefficients of determination $\left(\mathrm{R}^{2}\right.$ ) ranging from 0.14 to 0.35 (Supplemental Table S1; https://doi.org/10.3168/jds.2017-13139). Furthermore, in addition to MPN, d 21 sporeformer counts were significantly correlated with DI through d 14 Bacillales spore counts and raw milk BtSCC, with $\mathrm{R}^{2}$ ranging from 0.13 to 0.30 (Supplemental Table S1). With correlation coefficients all $\leq 0.35$, we observed no strong correlation between MPN or d-21 Bacillales spore count with any of the raw milk tests.

\section{Bacillales Genera Isolated from SP-Treated Milk Samples}

Initial analysis of rpoB AT data for 746 isolates allowed us to identify 442 representative bacterial isolates obtained from 120 milk samples (12 milk samples per farm) at different time points after SP treatment (Table 3). Representative isolates were obtained by including only a single isolate if multiple isolates with the same AT were obtained from the same sample and on the same day of refrigerated storage. Most of these representative isolates were classified as Bacillus spp. (70.8\%; 313/442 isolates) or Paenibacillus spp. (28.3\%; 125/442 isolates; Table 3). Lysinibacillus spp. and Viridibacillus arvi/arenosi accounted for 0.9\% (4/442) of the total isolates (Table 3).

The predominant Bacillus and Paenibacillus species among the characterized isolates were $B$. licheniformis, B. pumilus, and B. weihenstephanensis and P. cf. peori$a e$ and $P$. odorifer (Table 3). For isolates obtained from milk at DI and d 7 after SP, 86.2 and $13.8 \%$ were classified as Bacillus (193/224) and Paenibacillus (31/224), respectively; for isolates obtained from milk at d 14 and $21,56.1 \%(120 / 214)$ and $43.9 \%(94 / 214)$ were classified 
MASIELLO ET AL.

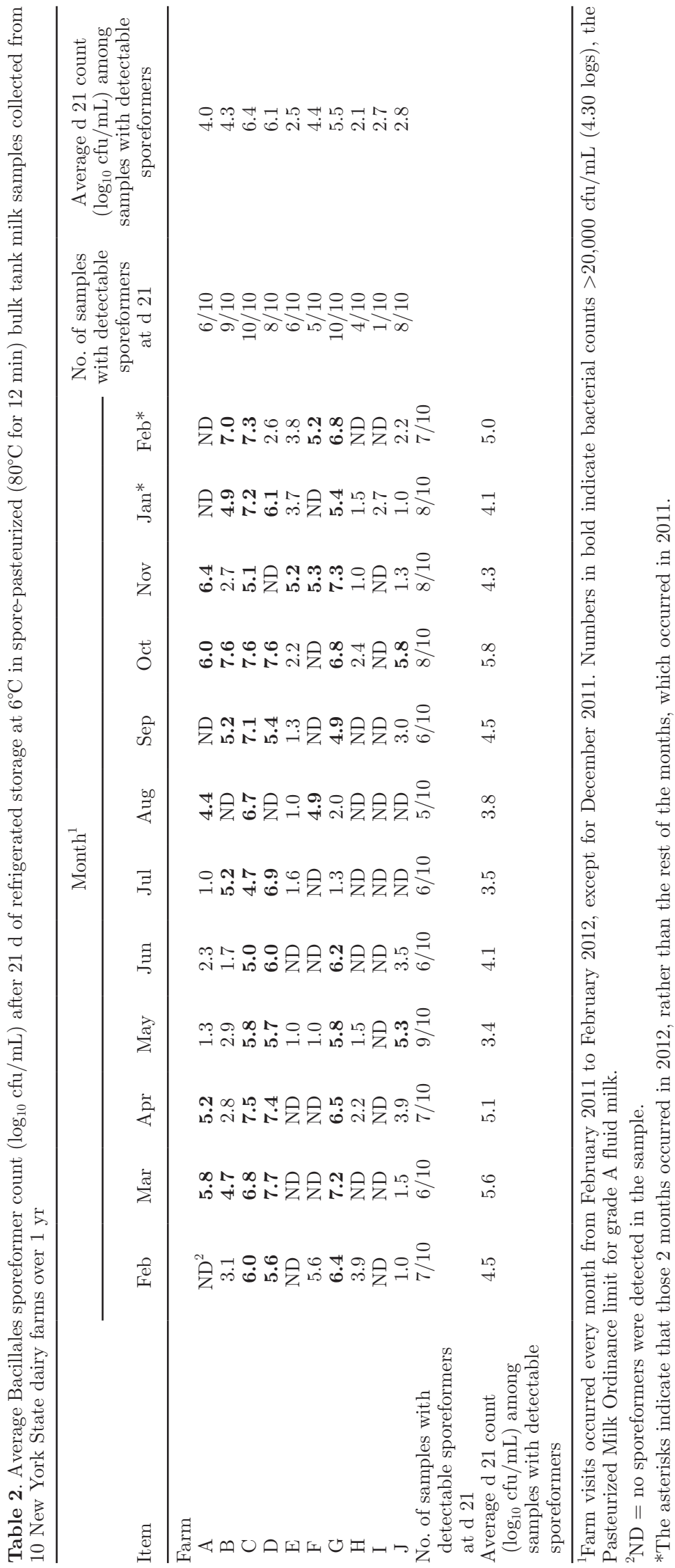


as Bacillus and Paenibacillus, respectively. The number of Bacillus and Paenibacillus spp. isolated significantly differed by month $(P<0.001 ;$ Fisher's Exact Test $)$. Months with the highest proportion of Bacillus isolates obtained were November, September, and August with 94, 86, and 79\%, respectively (Supplemental Table S2; https://doi.org/10.3168/jds.2017-13139). The highest proportions of Paenibacillus isolates were obtained in March, April, and February with 55, 40, and 36\%, respectively (Supplemental Table S2).

The $\operatorname{rpoB}$ sequence data allowed for further classification of isolates to specific subtypes (rpoB AT); 89 unique AT were found among the characterized isolates representing all farms. The most prevalent AT were AT-1 (B. licheniformis; 61 isolates), AT-3 (B. weihenstephanensis; 37 isolates), AT-20 (B. pumilus; 32 isolates), AT-6 (B. licheniformis; 31 isolates), AT-179 (P. cf. peoriae; 25 isolates), and AT-337 (B. pumilus; 22 isolates). For 9 of the study farms, isolates representing the same genus were obtained from samples collected during different months (Table 4). For the same 9 farms, isolates with the same AT were obtained from samples collected during at least 2 different months. For example, the majority of AT-337 isolates (15 of the 22 isolates with this AT) were obtained from farm C; on this farm, AT-337 isolates were obtained in 11 of the 12 months studied (Table 4). In contrast, AT-1 was reisolated from 9 farms, consistent with previous reports that this is the most common Bacillus AT in raw milk (Ranieri et al., 2009). The single farm (farm I; See Table 4) that did not have any AT reisolated during different months was also the farm with the fewest representative isolates obtained ( $\mathrm{n}=6$ isolates).

\section{Management Factors Associated with Bacillales Spore Detection at Day 21}

After variable selection for the logistic regression, 3 management factors were significantly associated (all at $P<0.01$ ) with the probability of Bacillales spore detection on d 21 in SP-treated bulk tank milk: (1) frequency of bulk tank area cleaning; (2) whether skid steer scrapers were used to clean the housing area; and (3) whether problem cows were segregated during milking (Table 5). Two more variables - "stall cleanliness" and "other stall cleaning method used"-were retained in the final model but were not significant. We detected no significant association between either weather factors or month of sampling and the probability of d-21 Bacillales spore detection in SP-treated bulk tank milk. For the factor "frequency of bulk tank area cleaning," each additional cleaning was associated with a 14.6-fold decrease in the odds of d-21 Bacillales spore detection. Use of skid steer scrapers was associated with a 150.2fold decrease in the odds of d-21 Bacillales spore detection, and segregation of problem cows during milking time was associated with a 44.3-fold decrease in the odds of d-21 Bacillales spore detection.

Table 3. Numbers and prevalence of Bacillales genera and species obtained at the initial day (DI) and at d 7,14 , and 21 of refrigerated storage at $6^{\circ} \mathrm{C}$, from spore-pasteurized bulk tank milk samples collected from 10 New York State farms over 1 yr

\begin{tabular}{|c|c|c|c|c|c|c|}
\hline $\begin{array}{l}\text { Bacterial genus } \\
\text { and species }{ }^{1}\end{array}$ & DI & d 7 & d 14 & d 21 & Total no. & $\%$ \\
\hline Bacillus spp. (total) & 100 & 93 & 67 & 53 & 313 & 70.8 \\
\hline B. aerophilus & 0 & 0 & 1 & 0 & 1 & 0.2 \\
\hline B. cf. aerophilus & 8 & 3 & 0 & 0 & 11 & 2.5 \\
\hline B. cereus sensu lato & 3 & 1 & 6 & 3 & 13 & 2.9 \\
\hline B. clausii & 1 & 0 & 0 & 1 & 2 & 0.5 \\
\hline B. horneckiae & 1 & 0 & 0 & 0 & 1 & 0.2 \\
\hline B. licheniformis & 34 & 43 & 12 & 10 & 99 & 22.4 \\
\hline B. pumilus & 36 & 29 & 13 & 13 & 91 & 20.6 \\
\hline B. safensis & 6 & 5 & 4 & 1 & 16 & 3.6 \\
\hline Bacillus sp. & 1 & 0 & 1 & 0 & 2 & 0.5 \\
\hline B. subtilis sensu lato & 9 & 3 & 3 & 2 & 17 & 3.8 \\
\hline B. weihenstephanensis & 1 & 9 & 27 & 23 & 60 & 13.6 \\
\hline Paenibacillus spp. (total) & 6 & 25 & 49 & 45 & 125 & 28.3 \\
\hline P. amylolyticus sensu lato & 1 & 0 & 1 & 2 & 4 & 0.9 \\
\hline P. cf. cookii & 2 & 0 & 2 & 0 & 4 & 0.9 \\
\hline P. cf. peoriae & 3 & 10 & 23 & 23 & 59 & 13.4 \\
\hline P. graminis & 0 & 1 & 2 & 2 & 5 & 1.1 \\
\hline P. odorifer & 0 & 14 & 20 & 15 & 49 & 11.1 \\
\hline Paenibacillus sp. & 0 & 0 & 1 & 3 & 4 & 0.9 \\
\hline Lysinibacillus sp. & 0 & 0 & 0 & 1 & 1 & 0.2 \\
\hline Viridibacillus arvi/arenosi & 0 & 0 & 2 & 1 & 3 & 0.7 \\
\hline Total & 106 & 118 & 118 & 100 & 442 & 100 \\
\hline
\end{tabular}

${ }^{1}$ Sensu lato $=$ in the broad sense; cf. = unspecified identification (resembling the named species). 


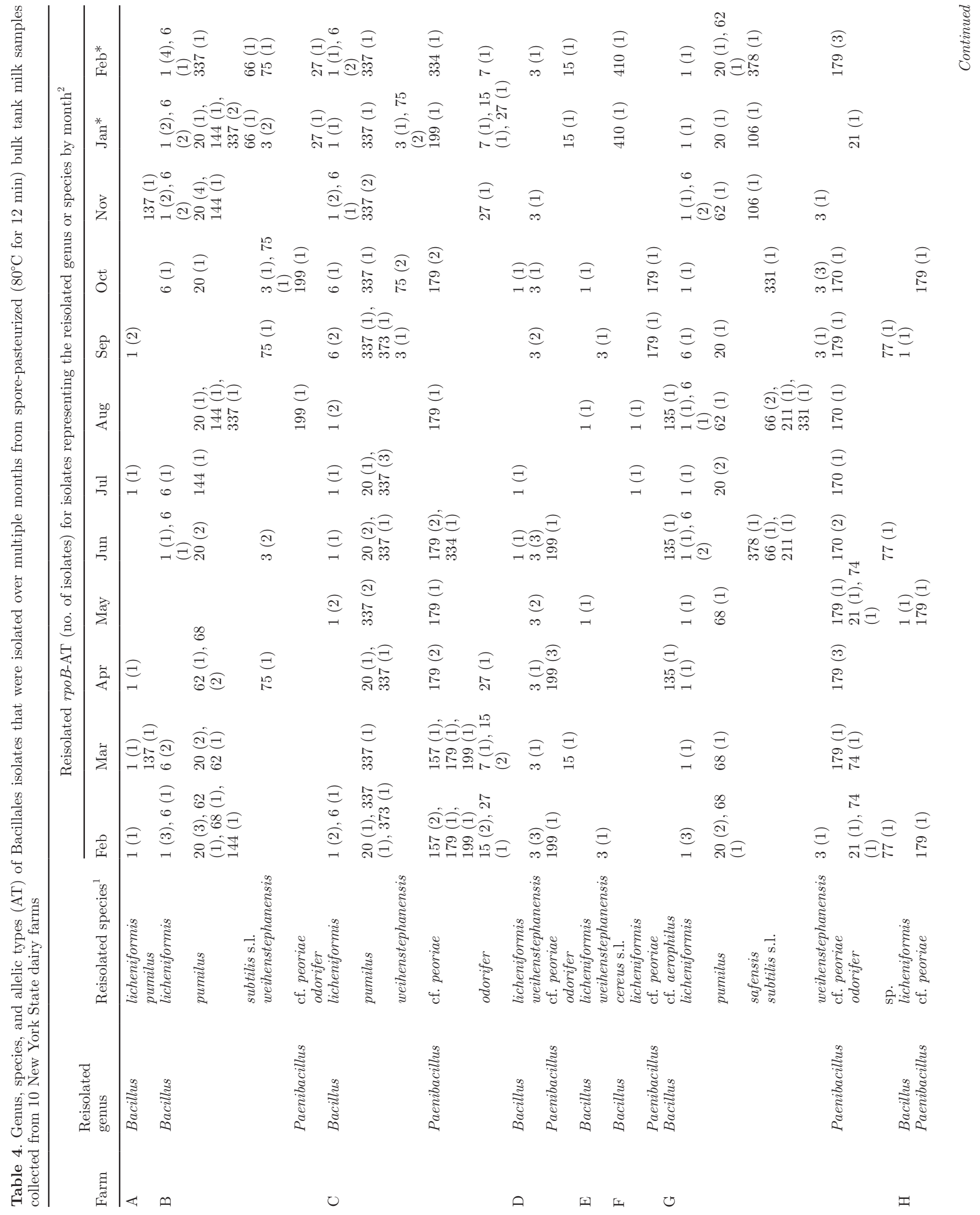


LONGITUDINAL STUDY OF PSYCHROTOLERANT SPOREFORMERS

\section{DISCUSSION}

This longitudinal study quantified associations between dairy farm management practices and psychrotolerant Bacillales spore levels in heat-treated refrigerated milk over the course of 1 yr. Multivariate logistic regression analysis and correlation analysis identified 3 factors (frequency of bulk tank area cleaning, using a skid steer to clean the housing area, and segregating problem cows during milking) that were significantly associated with the probability of psychrotolerant Bacillales spore detection at $21 \mathrm{~d}$ of refrigerated storage after SP. These significant factors represent general cleanliness components of dairy farm management and suggest that adjustments to current cleaning practices and management of milking time factors may allow for better management of psychrotolerant Bacillales spoilage organisms and, therefore, pasteurized milk shelf-life performance.

\section{Farms with Low Levels of Psychrotolerant Bacillales Spore Contamination}

Psychrotolerant Bacillales spores have been identified as key factors limiting the shelf life of HTST fluid milk that is not exposed to post-processing contamination (Boor, 2001; Durak et al., 2006). If present, psychrotolerant Bacillales spores typically cause spoilage of HTST milk by d 17 to 21 of refrigerated storage at $6^{\circ} \mathrm{C}$ (Fromm and Boor, 2004). A previous cross-sectional study showed that bulk tank raw milk from $37.4 \%$ of 99 farms contained such low levels of psychrotolerant Bacillales spores that no spore outgrowth was observed in $100 \mathrm{~mL}$ of heat-treated milk over $21 \mathrm{~d}$ of storage at $6^{\circ} \mathrm{C}$ after SP treatment (using the same methodology applied in the current study; Masiello et al., 2014). However, the previous study did not determine whether farms consistently produce raw milk with low psychrotolerant Bacillales spore levels, which is a concern as variation in bacterial counts has been reported for bulk tank raw milk. Hayes and colleagues (2001) showed that $\mathrm{TBC}$ in a given farm can vary considerably; for example, bulk tank milk from 8 of 13 farms experienced occasional spikes, with TBC ranging from 4.2 to 5.8 $\log _{10} \mathrm{cfu} / \mathrm{mL}$. Consistent with previous data on TBC, our study supports that many farms show monthly variation in bulk tank raw milk contamination with psychrotolerant Bacillales spores. For example, 4 bulk tank raw milk samples from farm F showed high bacteria counts (all $>4.5 \operatorname{logs}$ ) at $\mathrm{d} 21$ post-SP, whereas the other 8 samples showed counts $<1.0 \log (\leq 10 \mathrm{cfu} / \mathrm{mL})$ at d 21 post-SP. Among the 10 farms enrolled, 2 (farms $\mathrm{H}$ and I) were consistently capable of producing milk that showed limited $(<3 \operatorname{logs})$ or no bacterial growth 
Table 5. Farm management practices significantly $(P<0.01)$ associated with probability of Bacillales spore detection in spore-pasteurized bulk tank milk samples after $21 \mathrm{~d}$ of refrigerated storage $\left(6^{\circ} \mathrm{C}\right)$

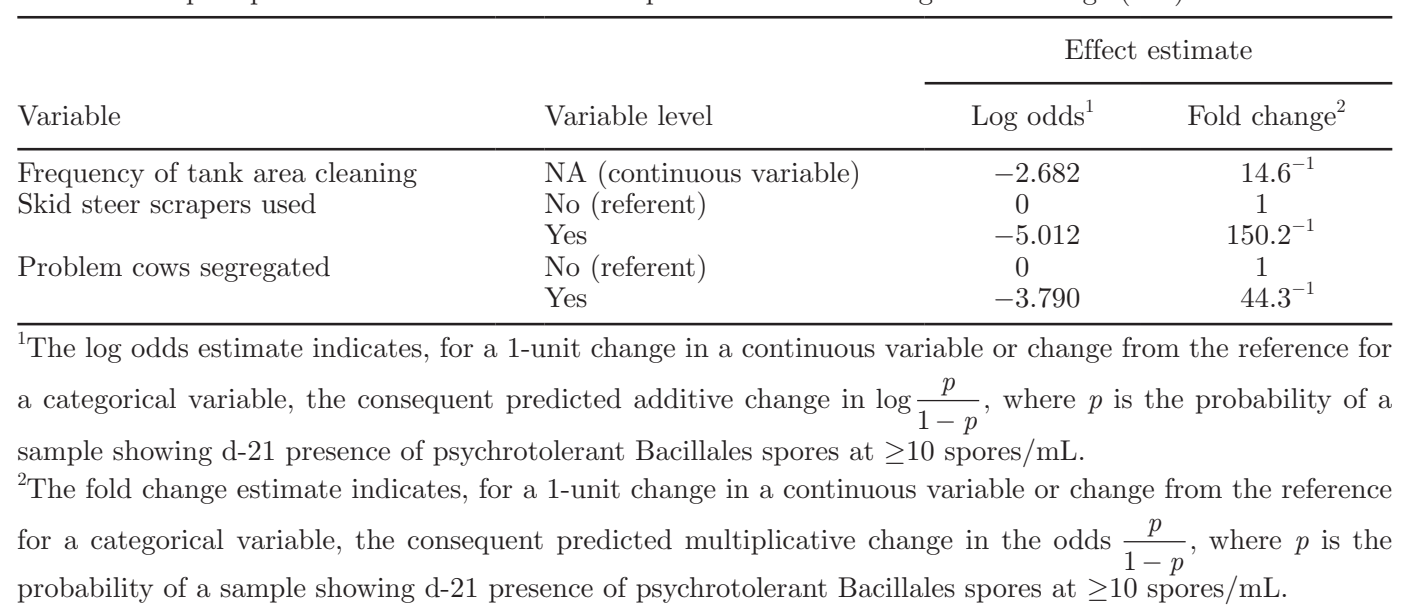

following SP treatment and $21 \mathrm{~d}$ of refrigerated storage. These results suggest that psychrotolerant Bacillales spore levels can be managed to be consistently low. Thus, it should be possible to develop a raw milk supply that could dependably be processed into fluid milk products that would show minimal microbial spoilage due to psychrotolerant Bacillales spore outgrowth.

Appropriate diagnostic tests are key tools that allow producers to manage raw milk quality. Traditionally, spore count methods are not routinely used to monitor raw milk quality; in particular, a psychrotolerant Bacillales spore count test would be difficult to use routinely, as the time to result would be at least $10 \mathrm{~d}$ (these tests involve a 10-d incubation of plates at $6^{\circ} \mathrm{C}$ ). Although we found significant correlations between commonly used raw milk quality tests and bacterial counts at d 21 post-SP, the coefficient of determination values were not very high (ranging from 0.00 to 0.13 ), implying a limited ability of the raw milk tests to predict bacterial counts d 21 after SP (Supplemental Table S1; https:// doi.org/10.3168/jds.2017-13139). These results are consistent with a previous cross-sectional study that also reported low coefficient of determination values between the raw milk quality tests and bacterial counts at d 21 post-SP from bulk tank samples from 99 NYS dairy farms (Masiello et al., 2014). Additionally, a previous study in New York examining, over 1 yr, associations between raw milk microbiological quality parameters and microbiological performance data over shelf life for HTST-pasteurized fluid milk products found that there was little predictive power for raw milk microbiological tests currently used in the dairy industry (e.g., PBC or PI count) and pasteurized product shelf life (Martin et al., 2011). On the other hand, the current study found modest correlations between psychrotolerant Bacillales spore MPN counts and bacterial counts at d 21 post-SP.
Although the MPN test seems to be the most useful test for quantification of psychrotolerant Bacillales spores, it is time and labor intensive. Although work has been done to develop a real-time quantitative PCR assay for specific detection of Paenibacillus spp. (Ranieri et al., 2012), this assay does not detect psychrotolerant Bacillus spp. or other psychrotolerant Bacillales that represent different genera (e.g., Viridibacillus spp.). Our results suggest that a rapid molecular test capable of quantitative detection of all psychrotolerant Bacillales would facilitate management of raw milk quality for improved HTST milk shelf life; increased availability of genomic information for psychrotolerant Bacillales spores (Moreno Switt et al., 2014) may provide an opportunity for the development of these types of tests.

\section{Bacillus and Paenibacillus Predominate After SP}

Bacillus spp. and Paenibacillus spp. were the predominant Bacillales spores isolated from SP milk in the current study. The overall frequency of isolation of Bacillus and Paenibacillus spp. differed significantly between months during the yearlong study. Our data indicated that the highest proportion of Bacillus spp. was isolated in the late autumn and winter, whereas the highest proportion of Paenibacillus spp. was isolated in the late winter and spring. Previous work from a 1994 Scottish study assessing seasonal occurrences of Bacillus spp. in raw milk found that the incidence of $B$. pumilus, B. licheniformis, and B. subtilis, classified in the study as mesophilic sporeformers, was highest during the winter (specifically from November to March; Sutherland and Murdoch, 1994). These observations suggest that certain sporeformer isolates may be more likely to be isolated during cooler months and indicated that further work is needed to identify the relationship 
between climate factors and specific psychrotolerant Bacillales genera associated with bulk tank raw milk.

In the current study, Bacillus represented the genus most commonly isolated from samples, representing 11 of the 12 sampling months. By comparison, in a previous cross-sectional study evaluating associations between farm practices and psychrotolerant Bacillales spores in bulk tank milk, 71.4 and $26.4 \%$ of all isolates (obtained from SP milk over $21 \mathrm{~d}$ of storage at $6^{\circ} \mathrm{C}$ ) were classified as Bacillus spp. and Paenibacillus spp., respectively (Masiello et al., 2014). These findings are consistent with previous studies, which have shown that Bacillus and Paenibacillus are the predominant Bacillales genera isolated from commercially HTSTpasteurized milk and milk products all over the world, including the United States (Fromm and Boor, 2004; Huck et al., 2008; Ranieri and Boor, 2009; Ivy et al., 2012; Masiello et al., 2014; Miller et al., 2015a), Europe (Phillips and Griffiths, 1986; Sutherland and Murdoch, 1994; Schmidt et al., 2012; Lücking et al., 2013), and Africa (Aouadhi et al., 2013). Additionally, Bacillus, and to a lesser extent Paenibacillus spp., have been regularly isolated from environmental samples taken from dairy farms (Huck et al., 2007b; Ivy et al., 2012; Schmidt et al., 2012). In one previous study, the majority $(87 \%)$ of spores isolated from the dairy farm environment (bedding, feed, manure, soil, water, and bulk tank milk) were classified as Bacillus spp., whereas $13 \%$ of isolates were classified as Paenibacillus spp. (Huck et al., 2008). The percentage of isolates classified as Paenibacillus spp. in the current study was higher in milk at d 14 and 21 after SP compared with milk at DI and d 7. These results are consistent with previous studies of spoilage patterns in pasteurized milk that reported increasing isolation rates of Paenibacillus spp. over $21 \mathrm{~d}$ of refrigerated storage (Fromm and Boor, 2004; Ranieri et al., 2009; Ranieri and Boor, 2009; Masiello et al., 2014) as well as previous work showing that, among dairy-associated isolates, the majority of Paenibacillus spp. but very few Bacillus spp. have the ability to grow at low temperatures (Ivy et al., 2012). Overall, these data indicate that the predominant Bacillales spores in raw milk are typically Bacillus spp., which include psychrotolerant as well as mesophilic and thermophilic strains (Huck et al., 2008; Masiello et al., 2014; Miller et al., 2015b), whereas cold storage after both experimental and commercial HTST pasteurization selects for Paenibacillus spp., which are predominantly psychrotolerant, as well as psychrotolerant Bacillus strains.

\section{On-Farm Management Practices}

We identified 3 management factors significantly associated with d-21 sporeformer presence in raw bulk tank milk. More frequent cleaning of the bulk tank area, the use of a skid steer to scrape the housing area, and segregating problem cows during milking were all associated with lower probabilities of d-21 Bacillales spore detection in SP-treated bulk tank raw milk. Although these factors are derived from specific survey questions, it is likely that all are proxies for general farm cleanliness rather than explicit management factors that can guarantee low Bacillales spore presence. For example, the use of a skid steer for housing area cleaning may (1) directly affect the cleanliness of cows entering the milking parlor and therefore affect spore presence, or (2) act as a proxy for the farm staff's priority to cleanliness and therefore affect spore presence.

The association of general cleanliness management factors with d-21 sporeformer presence is consistent with conclusions from previous studies, which noted that on-farm cleanliness factors relating to a cow's daily life (from housing to milking) can affect bacterial counts in bulk tank milk. Soil and manure have been previously identified as risk factors for milk contamination with psychrotolerant Bacillales spores in the general dairy farm environment (Vissers et al., 2007; Huck et al., 2008). In a Dutch study among 24 dairy farms, researchers observed a significant correlation between spore concentrations in bulk tank milk and in manure samples collected from both pasture and housing areas, noting that a higher spore concentration in manure was correlated with a higher $B$. cereus concentration in bulk tank milk (Vissers et al., 2007). In addition to farm environment cleanliness, cow hygiene (via teatend cleanliness) has been shown to be associated with bacteria counts in bulk tank milk (Elmoslemany et al., 2010). In a study of 153 herds on Prince Edward Island (Canada), both the total aerobic and preliminary incubation counts in bulk tank milk samples were significantly associated with the amount of dirt on teats, indicating that dirtier teats were associated with higher counts (Elmoslemany et al., 2010). Previous studies also support the importance of maintaining good hygiene from farm environment to cow, indicating the effect of housing hygiene on teat cleanliness (Plesch and Knierim, 2012) and, therefore, bacteriological quality of bulk tank raw milk (Elmoslemany et al., 2010). Our data suggest that managing overall farm cleanliness (via manure/dirt contamination reduction from housing to parlor to milkhouse) is a key intervention and a feasible strategy to reduce psychrotolerant Bacillales spore presence in bulk tank raw milk.

\section{CONCLUSIONS}

Consistent control of the presence of psychrotolerant Bacillales spoilage organisms throughout milk produc- 
tion and the milk-processing continuum is needed to produce high-quality and long-lasting fluid milk products. Our study identified that dairy farm management practices related to overall dairy farm cleanliness were associated with the presence of psychrotolerant Bacillales spores in bulk tank milk after $21 \mathrm{~d}$ at $6^{\circ} \mathrm{C}$ after heat treatment. These results suggest that on-farm adjustments in management decisions focused on both environmental and cow cleanliness may have a direct effect on psychrotolerant Bacillales spore presence and hence the shelf life of pasteurized fluid milk. As our data here included only a few environmental factors (e.g., temperature and rainfall) and were observational, additional studies on the potential associations between psychrotolerant sporeformer counts and a larger range of environmental factors (including interactions with management factors), and experimental rather than observational work relating to on-farm management practices may be valuable to further refine strategies to allow for consistent annual production of raw milk with low psychrotolerant Bacillales spore levels.

\section{ACKNOWLEDGMENTS}

This project was supported by the New York State Milk Promotion Advisory Board contract \#C200796 through the New York State Department of Agriculture and Markets (Albany, NY). The authors thank the management and employees of all participating farms, Cornell University Quality Milk Production Services (Ithaca, NY) technicians for sample and survey collection, as well as members of Cornell University Milk Quality Improvement Program for laboratory support.

\section{REFERENCES}

Ageitos, J. M., J. A. Vallejo, A. B. F. Sestelo, M. Poza, and T. G. Villa. 2007. Purification and characterization of a milk-clotting protease from Bacillus licheniformis strain USC13. J. Appl. Microbiol. 103:2205-2213.

Akaike, H. 1998. Information theory and an extension of the maximum likelihood principle. Pages 199-213 in Selected Papers of Hirotugu Akaike. 1st ed. E. Parzen, K. Tanabe, and G. Kitagawa, ed. Springer, New York, NY.

Aouadhi, C., A. Maaroufi, and S. Mejri. 2013. Incidence and characterisation of aerobic spore-forming bacteria originating from dairy milk in Tunisia. Int. J. Dairy Technol. 67:95-102. https://doi.org/ 10.1111/1471-0307.12088.

Bates, D., M. Maechler, B. Bolker, and S. Walker. 2013. lme4: Linear mixed-effects models using Eigen and S4. R Package version 1.005. Accessed Dec. 12, 2013. http://CRAN.R-project.org/package $=\operatorname{lm} 4$.

Boor, K. J. 2001. ADSA Foundation Scholar Award: Fluid dairy product quality and safety: Looking to the future. J. Dairy Sci. 84:1-11.

Collins, E. B. 1981. Heat resistant psychrotrophic microorganisms. J. Dairy Sci. 64:157-160.

Crielly, E. M., N. A. Logan, and A. Anderton. 1994. Studies on the bacillus flora of milk and milk products. J. Appl. Bacteriol. 77:256263.
Davidson, P. M., L. A. Roth, and S. A. Gambrel-Lenarz. 2004. Coliform and other indicator bacteria. Pages 196-197 in Standard Methods for the Examination of Dairy Products. 17th ed. H. M. Wehr and J. F. Frank, ed. Am. Public Health Assoc., Washington, DC.

Dugan, K. A., H. S. Lawrence, D. R. Hares, C. L. Fisher, and B. Budowle. 2002. An improved method for post-PCR purification for mtDNA sequence analysis. J. Forensic Sci. 47:811-818.

Durak, M. Z., H. I. Fromm, J. R. Huck, R. N. Zadoks, and K. J. Boor. 2006. Development of molecular typing methods for Bacillus spp. and Paenibacillus spp. isolated from fluid milk products. J. Food Sci. 71:M50-M56.

Dutt, K., P. Gupta, S. Saran, S. Misra, and R. Saxena. 2009. Production of milk-clotting protease from Bacillus subtilis. Appl. Biochem. Biotechnol. 158:761-772.

Elmoslemany, A. M., G. P. Keefe, I. R. Dohoo, J. J. Witchel, H Stryhn, and R. T. Dingwell. 2010. The association between bulk tank milk analysis for raw milk quality and on-farm management practices. Prev. Vet. Med. 95:32-40.

Fredrickson, J. K., and T. C. Onstott. 1996. Microbes deep inside the earth. Sci. Am. 275:68-73.

Fromm, H. I., and K. J. Boor. 2004. Characterization of pasteurized fluid milk shelf-life attributes. J. Food Sci. 69:M207-M214.

Gilliam, M. 1985. Microbes from apiarian sources: Bacillus spp. in frass of the greater wax moth. J. Invertebr. Pathol. 45:218-224.

Gilliam, M., S. L. Buchman, and B. J. Lorenz. 1984. Microbial flora of the larval provisions of the solitary bees, Centris pallida and Anthophora sp. Apidologie (Celle) 15:1-10.

Griffiths, M. W., and J. D. Phillips. 1990. Incidence, source and some properties of psychrotrophic Bacillus spp found in raw and pasteurized milk. Int. J. Dairy Technol. 43:62-66.

Hayes, M. C., R. Ralyea, S. Murphy, N. Carey, J. Scarlett, and K. Boor. 2001. Identification and characterization of elevated microbial counts in bulk tank raw milk. J. Dairy Sci. 84:292-298.

Huck, J. R., B. H. Hammond, S. C. Murphy, N. H. Woodcock, and K. J. Boor. 2007a. Tracking spore-forming bacterial contaminants in fluid milk-processing systems. J. Dairy Sci. 90:4872-4883.

Huck, J. R., M. Sonnen, and K. J. Boor. 2008. Tracking heat-resistant, cold-thriving fluid milk spoilage bacteria from farm to packaged product. J. Dairy Sci. 91:1218-1228.

Huck, J. R., N. H. Woodcock, R. D. Ralyea, and K. J. Boor. 2007b. Molecular subtyping and characterization of psychrotolerant endospore-forming bacteria in two New York State fluid milk processing systems. J. Food Prot. 70:2354-2364.

Ivy, R. A., M. L. Ranieri, N. H. Martin, H. C. den Bakker, B. M. Xavier, M. Wiedmann, and K. J. Boor. 2012. Identification and characterization of psychrotolerant sporeformers associated with fluid milk production and processing. Appl. Environ. Microbiol. 78:1853-1864.

Laird, D. T., A. Gambrel-Lenarz, F. M. Scher, T. E. Graham, and R. Reddy. 2004. Microbiological count methods. Pages 153-186 in Standard Methods for the Examination of Dairy Products. 17th ed. H. M. Wehr and J. F. Frank, ed. Am. Public Health Assoc., Washington, DC.

Lücking, G., M. Stoeckel, Z. Atamer, J. Hinrichs, and M. EhlingSchulz. 2013. Characterization of aerobic spore-forming bacteria associated with industrial dairy processing environments and product spoilage. Int. J. Food Microbiol. 166:270-279.

Martin, N. H., M. Ranieri, S. Murphy, R. Ralyea, M. Wiedmann, and K. Boor. 2011. Results from raw milk microbiological tests do not predict the shelf-life performance of commercially pasteurized fluid milk. J. Dairy Sci. 94:1211-1222.

Masiello, S. N., N. H. Martin, R. D. Watters, D. M. Galton, Y. H. Schukken, K. J. Boor, and M. Wiedmann. 2014. Identification of dairy farm management practices associated with the presence of psychrotolerant sporeformers in bulk tank milk. J. Dairy Sci. 97:4083-4096.

Miller, R. A., D. Kent, K. Boor, N. Martin, and M. Wiedmann. 2015a Different management practices are associated with mesophilic and thermophilic spore levels in bulk tank raw milk. J. Dairy Sci. 98:4338-4351. 
Miller, R. A., D. Kent, M. Watterson, K. Boor, N. Martin, and M. Wiedmann. 2015b. Spore populations among bulk tank raw milk and dairy powders are significantly different. J. Dairy Sci. 98:8492-8504.

Moreno Switt, A. I., A. D. Andrus, M. L. Ranieri, R. H. Orsi, R. Ivy, H. C. den Bakker, N. H. Martin, M. Wiedmann, and K. J. Boor. 2014. Genomic comparison of sporeforming bacilli isolated from milk. BMC Genomics 15:26. https://doi.org/10.1186/1471-2164 $-15-2$.

Nicholson, W. L. 2002. Roles of bacillus endospores in the environment. Cell. Mol. Life Sci. 59:410-416.

Phillips, J. D., and M. W. Griffiths. 1986. Factors contributing to the seasonal variation of Bacillus spp. in pasteurized dairy products. J. Appl. Bacteriol. 61:275-285.

Plesch, G., and U. Knierim. 2012. Effects of housing and management conditions on teat cleanliness of dairy cows in cubicle systems taking into account body dimensions of the cows. Animal $6: 1360-1368$

R Core Team. 2014. R: A Language and Environment for Statistical Computing. R Foundation for Statistical Computing, Vienna, Austria, 2012.

R Studio. 2012. R studio: Integrated development environment for $\mathrm{R}$. https://www.rstudio.com/.

Ranieri, M. L., and K. Boor. 2009. Short communication: Bacterial ecology of high-temperature, short-time pasteurized milk processed in the United States. J. Dairy Sci. 92:4833-4840.

Ranieri, M. L., J. R. Huck, M. Sonnen, D. M. Barbano, and K. J. Boor. 2009. High temperature, short time pasteurization temperatures inversely affect bacterial numbers during refrigerated storage of pasteurized fluid milk. J. Dairy Sci. 92:4823-4832.

Ranieri, M. L., R. A. Ivy, W. R. Mitchell, E. Call, S. N. Masiello, M. Wiedmann, and K. J. Boor. 2012. Real-time PCR detection of Paenibacillus spp. in raw milk to predict shelf life performance of pasteurized fluid milk products. Appl. Environ. Microbiol. 78:5855-5863.
Sarkar, A. 1991. Isolation and characterization of thermophilic, alkaliphilic, cellulose-degrading Bacillus thermoalcaliphilus sp. nov. from termite (Odontotermes obesus) mound soil of a semiarid area. Geomicrobiol. J. 9:225-232.

Scheldeman, P., M. Rodríguez-Díaz, J. Goris, A. Pil, E. De Clerck, L. Herman, P. De Vos, N. A. Logan, and M. Heyndrickx. 2004. Bacillus farraginis sp. nov., Bacillus fortis sp. nov. and Bacillus fordii sp. nov., isolated at dairy farms. Int. J. Syst. Evol. Microbiol. $54: 1355-1364$

Schmidt, V. S., V. Kaufmann, U. Kulozik, S. Scherer, and M. Wenning. 2012. Microbial biodiversity, quality and shelf life of microfiltered and pasteurized extended shelf life (ESL) milk from Germany, Austria and Switzerland. Int. J. Food Microbiol. 154:1-9.

Sutherland, A. D., and R. Murdoch. 1994. Seasonal occurrence of psychrotrophic Bacillus species in raw milk, and studies on the interactions with mesophilic Bacillus spp. Int. J. Food Microbiol. 21:279-292.

te Giffel, M. C., A. Wagendorp, A. Herrewegh, and F. Driehuis. 2002. Bacterial spores in silage and raw milk. Antonie van Leeuwenhoek 81:625-630.

Vaerewijck, M. J., P. De Vos, L. Lebbe, P. Scheldeman, B. Hoste, and M. Heyndrickx. 2001. Occurrence of Bacillus sporothermodurans and other aerobic spore-forming species in feed concentrate for dairy cattle. J. Appl. Microbiol. 91:1074-1084.

Vissers, M. M., M. Te Giffel, F. Driehuis, P. De Jong, and J. Lankveld. 2007. Minimizing the level of bacillus cereus spores in farm tank milk. J. Dairy Sci. 90:3286-3293.

Washam, C., H. Olson, and E. Vedamuthu. 1977. Heat-resistant psychrotrophic bacteria isolated from pasteurized milk. J. Food Prot. 40:101-108.

Wickham, H., and R. Francois. 2016. dplyr. A Grammar of Data Manipulation. R package version 0.5.0. Accessed Dec. 12, 2013. https:// CRAN.R-project.org/package=dplyr. 